\title{
MASS, VOLUME AND MOISTURE EXCHANGE DURING CARROT ROOT BLANCHING
}

\section{PROMENA MASE, ZAPREMINE I VLAŽNOSTI PRILIKOM BLANŠIRANJA KORENA MRKVE}

\author{
Ondrej PONJIČAN", Anđelko BAJKIN*, Dragi RADOMIROVIĆ ${ }^{*}$, \\ Mladen IVANIŠEVIĆ*, Zoran STAMENKOVIĆ \\ *University of Novi Sad, Faculty of Agriculture, 21000 Novi Sad, Trg Dositeja Obradovića8, Serbia \\ e-mail: ondrej.ponjican@polj.uns.ac.rs
}

\begin{abstract}
Blanching is a regular procedure during the vegetable products processing like drying, freezing or canning). In this paper, testing was the influence of blanching carrot root in heated water temperature 80 and $100{ }^{\circ} \mathrm{C}$ for a period of 1,3 and 5 minutes. Carrot root samples had shape of the cylinders height of $10 \mathrm{~mm}$ and an average diameter of $30 \mathrm{~mm}$. The highest values mass change of 6.81 and $5.71 \%$ were measured for treatment 5 minutes at temperature 80 and $100{ }^{\circ} \mathrm{C}$. For the same blanching regimes measured was the biggest exchange of volume 10.20 and $6.50 \%$. Exchanging the moisture was in the range from 1.30 to $0.79 \%$ depends on the length of blanching period. It was found a statistically significant reduction in mass and volume of samples carrot during blanching in water. Increasing time and temperature the blanching adversely affect the loss of mass and volume sliced carrot root. From the mentioned, the blanching sliced carrots roots should use other methods of blanching (steam or microwave blanching).

Key words: carrots, blanching, processing, mass, volume, humidity.
\end{abstract}

\section{REZIME}

Blanširanje je redovni postupak prilikom dorade povrtarskih proizvoda, kao što je sušenje, zamrzavanje, konzerviranje. U ovom radu ispitivan je uticaj blanširanja korena mrkve u zagrejanoj vodi na temperaturi 80 i $100^{\circ} \mathrm{C}$, u trajanju od 1 , 3 i 5 minuta. Za potrebe ispitivanja, uzorci korena mrkve su sečeni i formirani su cilindri visine $10 \mathrm{~mm}$ i prosečnog prečnika $30 \mathrm{~mm}$. Povećanje promene mase od 6,81 i 5,71\% izmereno je pri blanširanju tokom 5 minuta pri temperaturi vode od 80 i $100^{\circ} \mathrm{C}$. Za navedene režime blanširanja najveće smanjenje zapremine uzorka bilo je 10,20 i 6,50\%. Promena vlažnosti korena mrkve usled blanširanja na temperaturi vode od $80^{\circ} \mathrm{C}$ bila je u granicama od 1,30 do $0,74 \%$, u zavisnosti od dužine trajanja procesa blanširanja. Ovim ispitivanjem utvrđeno je značajno smanjenje mase i zapremine uzoraka korena mrkve prilikom blanširanja u vodi. Povećanje dužine trajanja i temperature blanširanja negativno utiče na gubitak mase i zapremine sečenog korena mrkve. Iz navedenog, za blanširanje rezanog korena mrkve treba koristiti druge načine blanširanja (blanširanje vodenom parom ili mikrotalasno blanširanje).

Ključne reči: mrkva, blanširanje, dorada, masa, zapremina, vlažnost.

\section{INTRODUCTION}

Blanching is the simple technological operation consisting in increasing temperature of the fruit for the purpose of inactivating enzymes, modifying texture, preserving color, flavor, and nutritional value, and removing trapped air (Reyes De Corcuera et al., 2004).

Blanching with hot water lasts longer time interval, which leads to leaching of minerals and nutrients such as vitamins and obtained effluents with large biological oxygen demand (BDO). Blanching with water steam is more energy efficient and produces a smaller quantity of BDO. Also leaching of nutrients is lower in the steam blanching compared to the blanching water. Microwave blanching has great potential especially from the standpoint of improving product quality and reducing the amount of waste matter and expects its industrial application in the coming years.

Blanching of vegetables are usually performed by steam or hot water, usually over a period of 1-10 minutes at temperatures $75-95{ }^{\circ} \mathrm{C}$ depending on the type of vegetable (Cano, 1996). By increasing time and temperature blanching carrot color becomes darker due to changes in carotenoid pigments. Blanching can have a negative impact on nutrients such as vitamins and phenolic compounds that are relatively unstable when exposed to heat treatments (Prochasha et al., 2000). By adding of calcium or a combination of blanching and calcium can improve the mechanical properties of cooked carrots (Siliha et al., 1996). Smout et al. (2005) recommend a low value temperature blanching because of improved texture carrots. One possible solution is the treatment at a temperature of $70^{\circ} \mathrm{C}$ over a period of 30 minutes, followed by immersion in a $0.5 \%$ solution of calcium over a period of 1 hour.

In practice a stepwise blanching is often used, where at lower temperature the pectin-methyl-esterase (PME) activates, and at a higher temperature of the enzymatic activity is inactivated. Effects of low temperature blanching on texture, microstructure and rehydration capacity of carrots investigated Sanjuán et al., (2010). During the tests stepwise blanching was compared (10 min, $65{ }^{\circ} \mathrm{C}, 50$ minutes holding time $1 \mathrm{~min}$ and $95{ }^{\circ} \mathrm{C}$ ) to the conventional blanching process $\left(95^{\circ} \mathrm{C}, 1 \mathrm{~min}\right)$. The influence of blanching on texture change is determined by the measuring place of xylem and phloem through the puncture test. Between the stepwise blanching and the fresh sample there is not statistically significant difference between the maximum penetration forces at the significance level of $5 \%$. For samples blanched by conventional method resulted in statistically significantly lower values.

Impact of blanching treatments on the nutritional and sensory properties of oven dried carrot slices interrogated by Agiriga et al. (2015). Blanching was performed with clean water and a salt solution of a concentration of 5 and $10 \%$, at a temperature of 80 , 90 and $100{ }^{\circ} \mathrm{C}$ over a period of $5 \mathrm{~min}$. By sensory analyses were 
determined the most suitable properties of samples of carrot root, which is blanched at a temperature of $80^{\circ} \mathrm{C}$ in a $5 \%$ solution.

The aim of the research was to measure the mass, volume and moissture exchange in carrot root samples depending on the temperature and the blanching time interval. The measured values provide determination the impact of blanching regime on exchanges in the sample and the selection of the optimal blanching regime. The water losses during blanching represent a major drawback, which is necessary to examine in detail for each type of fruit.

\section{MATERIAL AND METHOD}

Experimental studies were performed in the Laboratory of Biosystems Engineering, Department of Agricultural Engineering, Faculty of Agriculture Novi Sad. Fresh carrot root hybrids "bolero" used for testing is provided directly from the manufacturer from Begeč. For the purposes of measurement standard carrot roots were chosen, with uniform diameter and length. From the central part of the roots were formed cylinders of uniform height of $10 \mathrm{~mm}$ average diameter of $30.7 \mathrm{~mm}$. To determine the mass and volume exchange 10 samples (cylinders) were used. The mass of carrot root samples before and after blanching is measured by the analytical balances (tab. 1). Mass of fresh carrot is subordinated to the sample total mass of 71.27 g. Average mass of samples to determinate moisture was $35 \mathrm{~g}$. Moisture content of carrot root samples in individual stages of the was determined by thermogravimetric methods (Službeni list, 1983) in a laboratory oven at $105^{\circ} \mathrm{C}$ for a period of 24 hours. The water used for blanching is heated by an electric heater. A water temperature control is performed by using a mercury thermometer (tab. 1). The period of blanching period was measured using a stopwatch. Archimed principe was used to determine apperent volume of carrot samples by equation:

$V=\frac{m_{I I}-m_{I}}{\rho_{s}}$

where is:

- mass of water mI (g),

- mass of sample in water mII (g),

- density of water qs (kg).

Table 1. Measurement equipments used in research process

\begin{tabular}{|c|c|c|}
\hline $\begin{array}{l}\text { Measured value, } \\
\text { the code in the } \\
\text { work and the unit }\end{array}$ & $\begin{array}{l}\text { Name of product, } \\
\text { manufacturer, model }\end{array}$ & $\begin{array}{l}\text { Measurement range, } \\
\text { resolution, } \\
\text { instrument accuracy }\end{array}$ \\
\hline \begin{tabular}{|c|}
$\begin{array}{c}\text { The diameter and } \\
\text { height of the } \\
\text { sample } D ; H(\mathrm{~mm})\end{array}$ \\
\end{tabular} & $\begin{array}{c}\text { Vernier callipers, TMA } \\
\text { INOX, D-6-1, Germany }\end{array}$ & $\begin{array}{c}0-200 \mathrm{~mm} ; 0,1 \mathrm{~mm} ; \\
\pm 0,05 \mathrm{~mm}\end{array}$ \\
\hline $\begin{array}{l}\text { mass of the } \\
\text { sample } m(\mathrm{~g})\end{array}$ & $\begin{array}{c}\text { Analytical balance, } \\
\text { KERN 440-33N, } \\
\text { Germany } \\
\end{array}$ & $\begin{array}{l}0-200 \mathrm{~g} ; 0,01 \mathrm{~g} \\
\quad \pm 0,02 \mathrm{~g}\end{array}$ \\
\hline $\begin{array}{c}\text { The moisture } \\
\text { of the sample } \\
\omega_{v b}\left(\%_{\mathrm{vb}}\right)\end{array}$ & \begin{tabular}{|c|} 
Laboratory dryer \\
Sterimatic ST-11 \\
"Instrumentarija", \\
Zagreb Aluminum dishes \\
60x40mm \\
\end{tabular} & \\
\hline $\begin{array}{c}\text { The temperature } \\
t_{r}\left({ }^{\circ} \mathrm{C}\right)\end{array}$ & $\begin{array}{c}\text { Mercury hermometer; } \\
\text { Tlos, HRK-4-1001, } \\
\text { Zagreb } \\
\end{array}$ & $\begin{array}{c}0-110^{\circ} \mathrm{C} ; 1^{\circ} \mathrm{C} ; \\
\pm 0,5^{\circ} \mathrm{C}\end{array}$ \\
\hline $\begin{array}{c}\text { Time measurement } \\
\tau(\mathrm{min})\end{array}$ & $\begin{array}{c}\text { Digital clock with } \\
\text { stopwatch and alarm, } \\
\text { NOKIA 6300, Finland } \\
\end{array}$ & $\begin{array}{c}0-60 \mathrm{~min} ; \\
0,1 \mathrm{~s} ; \pm 0,1 \mathrm{~s}\end{array}$ \\
\hline
\end{tabular}

Method of work

Precise determination of exchanges in mass, volume and moisture in the process of blanching, expressed in precent, and performed by computation through equations 1-3. Special determined water loss (WL) from the equation (4), which which lists Uddin et al. (2004):

$$
\begin{aligned}
& \Delta m=\frac{m_{S V}-m_{B L}}{m_{S V}} \cdot 100,(\%) \\
& \Delta V=\frac{V_{S V}-V_{B L}}{V_{S V}} \cdot 100,(\%) \\
& \Delta w=\frac{w_{S V}-w_{B L}}{w_{S V}} \cdot 100,(\%) \\
& W L=\frac{m w_{S V}-m w_{B L}}{m_{S V}} \cdot 100,(\%)
\end{aligned}
$$

where is:

- exchange in mass $\Delta m(\%)$,

- mass of fresh sample $m_{S V}(\mathrm{~g})$,

- mass of blanched sample $m_{B L}(\mathrm{~g})$,

- mass of water in the fresh sample $m w_{S V}(\mathrm{~g})$,

- mass of water in the sample after the blanching $m w_{B L}$ (g),

- volume exchange $\Delta V(\%)$,

- volume of fresh sample $V_{S V}\left(\mathrm{~mm}^{3}\right)$,

- volume of blanched sample $V_{B L}\left(\mathrm{~mm}^{3}\right)$,

- moisture exchange $\Delta w(\%)$,

- moisture of fresh sample $w_{S V}(\%) \mathrm{i}$

- moisture of blanched sample $w_{B L}(\%)$.

- water loss $W L(\%)$.

Moisture of fresh and blanched sample is expressed in terms of wet basis $\mathrm{w}_{\mathrm{vb}}\left(\%_{\mathrm{vb}}\right)$. The temperature and duration of process are the basic characteristics of the process blanching. During the examination blanching was performed at a temperature of 80 to $100{ }^{\circ} \mathrm{C}$, wherein the blanching process lasted for 1,3 and 5 minutes. Obtained mean values were statistically processed using nonlinear regression and polynomial equation calculated second degree. To draw the graph, and to calculate the regression equation and the coefficient of determination software package Microsoft Office Excel 2007 was used. Using the software package Statistica 12 conducted testing F-test analysis of variance and LSD test at the significance level of $5 \%$.

\section{RESULTS AND DISCUSSION}

Moisture content of fresh carrot root samples was in range from 89.73 to $90.70 \%_{\mathrm{wb}}$, or an average of $90.30 \%_{\mathrm{wb}}$. Varying levels of moisture are properties of the agricultural material and the result is their inhomogeneity. The differences between the measured values before and after blanching are shown through their percentage share (Equation 3).

Mass, volume and moisture exchange, depending on the applied regime blanching are shown in Table 2. Exchange of blanching temperature influenced significant differences in mass and moisture exchanges (testing via F-test, ANOVA). The length of the procces blanching statistically significant influenced for 
all three investigated parameters. Interaction between blanching parameters (temperature $\mathrm{x}$ time) also had statistically significant influence at mass and volume exchange.

Table 2. Mass, volume and moisture exchange depend on blanching regime

\begin{tabular}{|c|c|c|c|c|c||}
\hline $\begin{array}{c}\text { Temperature } \\
\left({ }^{\circ} \mathrm{C}\right)\end{array}$ & $\begin{array}{c}\text { Time } \\
(\mathrm{min})\end{array}$ & $\begin{array}{c}\text { Mass } \\
\text { exchange } \\
\Delta m(\%)\end{array}$ & $\begin{array}{c}\text { Volume } \\
\text { exchange } \\
\Delta V(\%)\end{array}$ & $\begin{array}{c}\text { Moisture } \\
\text { exchange } \\
\Delta w(\%)\end{array}$ & $\begin{array}{c}\text { Water } \\
\text { loss } \\
\text { WL (\%) }\end{array}$ \\
\hline \multirow{4}{*}{80} & 1 & $0.87 \mathrm{~d} *$ & $2.17 \mathrm{c}$ & $1.44 \mathrm{a}$ & $1.30 \mathrm{a}$ \\
\cline { 2 - 7 } & 3 & $4.91 \mathrm{~b}$ & $4.38 \mathrm{bc}$ & $1.04 \mathrm{a}$ & $0.94 \mathrm{a}$ \\
\cline { 2 - 7 } & 5 & $6.69 \mathrm{a}$ & $10.45 \mathrm{a}$ & $0.82 \mathrm{a}$ & $0.74 \mathrm{a}$ \\
\hline \multirow{3}{*}{100} & 1 & $3.62 \mathrm{c}$ & $4.41 \mathrm{bc}$ & $0.83 \mathrm{a}$ & $0.76 \mathrm{a}$ \\
\cline { 2 - 7 } & 3 & $5.27 \mathrm{~b}$ & $5.70 \mathrm{~b}$ & $-0.39 \mathrm{~b}$ & $-0.35 \mathrm{~b}$ \\
\cline { 2 - 7 } & 5 & $5.72 \mathrm{ab}$ & $6.49 \mathrm{~b}$ & $-0.88 \mathrm{~b}$ & $-0.79 \mathrm{~b}$ \\
\hline
\end{tabular}

*letter marks are obtained using LSD test at the significance level of $5 \%$.

The highest values of mass exchanges were measured while blanching for $5 \mathrm{~min}$, test temperature for both 80 and $100{ }^{\circ} \mathrm{C}$ and amounted to 6.69 and $5.72 \%$. Also the high value achieved for the period blanching $3 \mathrm{~min}$, where there has been a reduction of mass values 4.91 and $5.27 \%$.

By analyzing volume exchange, were determined statistically large and significant differences depending on the length of time blanching of 2.17 to $10.45 \%$ for a temperature of $80{ }^{\circ} \mathrm{C}$. For blanching temperature of $100{ }^{\circ} \mathrm{C}$ showed no statistically significant exchange in volume depending on the length of the blanching process. Volume exchange ranged from 4.41 to 6.49 $\%$

The overall moisture changes of the sample operate two basic processes: leaching of dry matter in the water that runs blanching and water infiltration, which is performed in the sample blanching carrot. At the beginning of the blanching process is more pronounced lowering of moisture sample (solids wash). Values of reduction moisture are relatively low within the range of 1.44 to $0.83 \%$ depending on the blanching temperature. Extending the duration blanching proces, more water penetrates into the tissue sample and increases its moisture content. After 5 minutes, blanching at a temperature of $100{ }^{\circ} \mathrm{C}$ moisture content of the sample is increased by $0.88 \%$ relative to the moisture of the sample before blanching. Length of the period of blanching revealed statistically significant differences of moisture exchanges at the significance level of $5 \%$.

Water loss (WL) were measured identical addiction like moisture exchanging $(\Delta w)$.

The differences in values (Table 2) are result of the calculation method. Moisture exchanging is calculated by the value of the moisture of fresh and blanched samples (Equation 3), a loss of water through the mass of fresh and blanched samples (Equation 4). Using non-linear regression analysis were determined by the equations of second degree with a high degree of correlation describes the exchange in mass, volume and moisture exchange of the sample carrot over time. The equations were determined for each temperature blanching (80 and $100^{\circ} \mathrm{C}$ ) in particular.

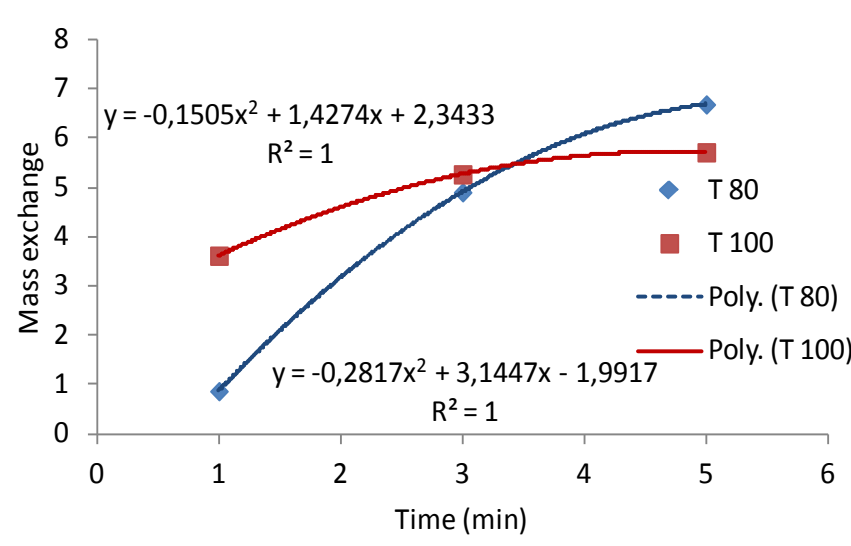

a)

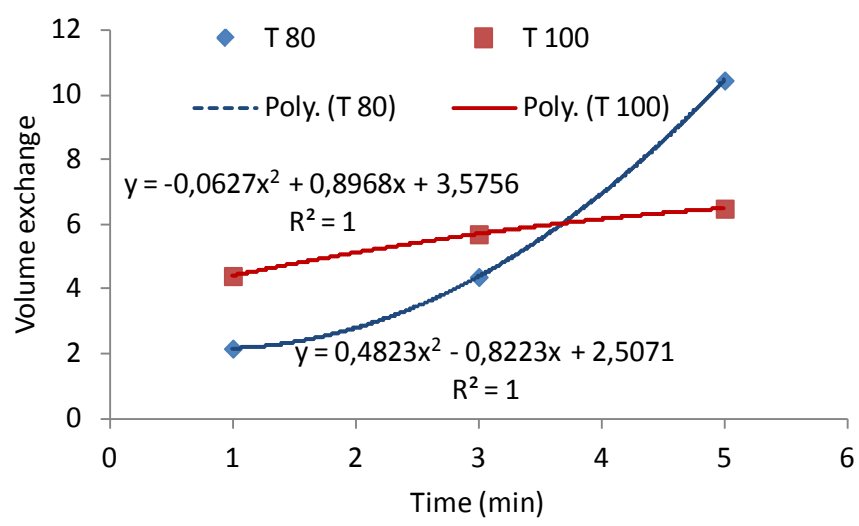

b)

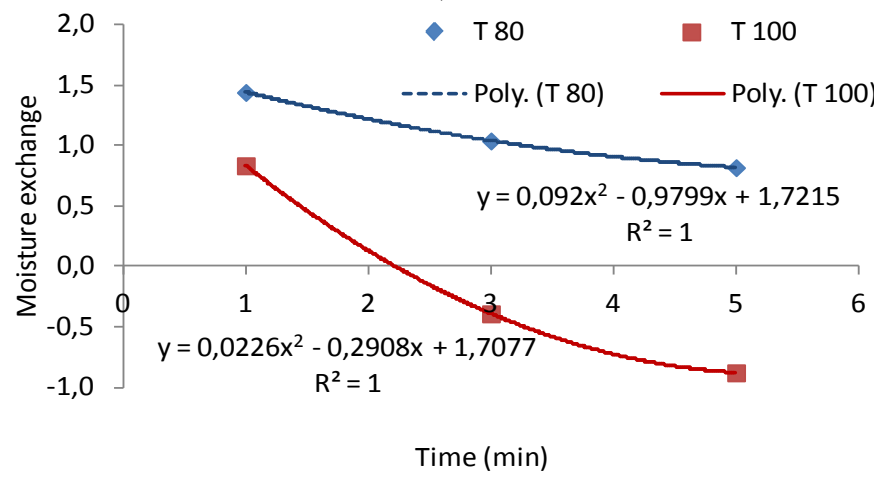

c)

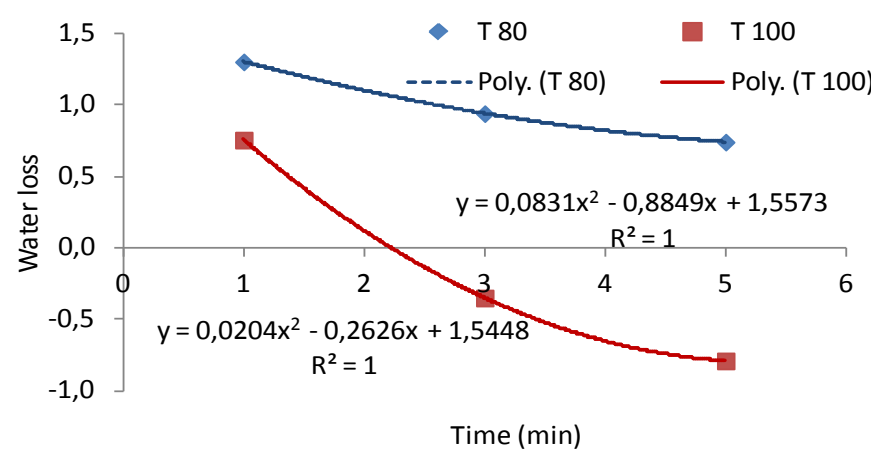

d)

Fig. 1. Effect of water temperature and the time of blanching carrot root samples to: a) mass exchange $(\Delta m)$; b) volume exchange $(\Delta V) ; c)$ moisture content exchange $(\Delta w) ; d)$ water loss (WL) 
The pocture clearly shows the effect of temperature and duration of blanching to change the parameters observed during blanching carrot root samples. Higher temperatures currently lead to greater mass and volume exchanges carrot root.

\section{Discussion}

Decreasing the mass of the sample during the blanching carrot in the water more than one author states, this primarily depends on the sample size and the regime blanching. In testing samples of carrot roots in the form of cylinders, $10 \mathrm{~mm}$ high at a temperature of $95^{\circ} \mathrm{C}$ for $3 \mathrm{~min}$, there was a mass reduction of $7.53 \%$, where in the loss of dry matter was $0.77 \%$ (Ponjičan et al., 2014). This is a significant loss of dry matter and the result of the leaching of nutrients in the process of blanching in water (De Corcuera Reyes et al., 2004). Ponjičan et al, (2013) state that the blanching celery root samples dimensions $15 \times 15 \times 15 \mathrm{~mm}$ decreased their mass by $1.61 \%$, and a decrease in volume was $10 \%$, while at the same time there has been an increase in humidity by $0.82 \%$. Blanching celery is carried out at a temperature of $95{ }^{\circ} \mathrm{C}$ for 3 min. Blanching carrots should not be applied before osmotic dehydration due to reduced semi permeability cell membrane (Ponting, 1973) and due to the lower $\beta$-carotene (Negi and Roy, 2000).

\section{CONCLUSION}

During the blanching water losses occur in the mass and volume of samples cut carrots. At the beginning of the blanching ( $1 \mathrm{~min})$, at a higher temperature blanching $\left(100{ }^{\circ} \mathrm{C}\right)$ occur substantially higher values of mass $(\Delta \mathrm{m})$ and volume $(\Delta \mathrm{V})$ exchange compared to the blanching temperature of $80{ }^{\circ} \mathrm{C}$. By extending the time interval blanching, mass and volume exchanges that are the results of different blanching temperature decreases. During blanching process of 5 minutes, higher mass $(\Delta \mathrm{m})$ and volume $(\Delta \mathrm{V})$ exchanges were determined for blanching temperature of $80{ }^{\circ} \mathrm{C}$. In future investigation, there should examine the behaviour of mass and volume exchanges during the steam blanching.

ACKNOWLEDGMENT: The research presented in this paper was financied by the Ministry of Education, Science and Technological Development, Republic of Serbia. Grant No TR 31058, 2011-2014.

\section{REFERENCES}

Agiriga, A.N., Iwe, M.O., Etoamaihe, U.J., Olaoye O.A. (2015). Impact of different blanching treatments on the nutritional and sensory properties of oven dried carrot slices. Sky Journal of Food Science, 4 (7), 102-107.
Cano, M.P. (1996). Vegetables. In L. E. Jeremiah (Ed.), Freezing effects on food quality. 520. New York: Marcel Dekker.

Negi, P.S., Roy, S.K. (2000). Effect of low-cost storage and packaging on quality and nutritive value of fresh and dehydrated carrots. Journal of the Science of Food and Agriculture, 80, 2169-2175.

Ponjičan, O., Babić, M., Radojčin, M., Bajkin, A., Radomirović, D. (2013). The physical behavior of celery during osmotic drying. Proceedings $3^{\text {rd }}$ International conference Sustainable Postharvest and Food Technologies - INOPTEP 2013. April 21st - 26th, 2013, Vrnjačka Banja, Serbia, 152-158.

Ponjičan, O., Bajkin, A., Radomirović, D., Pavkov, I., Radojčin, M. (2014). Promena mase korena mrkve u procesu osmotskog sušenja u zavisnosti od primenjenog predtretmana. Savremena poljoprivredna tehnika, 2(40), 97-106.

Ponting, J.D. (1973). Osmotic dehydration of fruits: Recent modifications and applications. Process Biochemistry, 8, 1822.

Prochaska, L.J., Nguyen, X.T., Donat, N., Piekutowski. W.V. (2000). Effects of food processing on the thermodynamic and nutritive value of foods: literature and database survey. Medical Hypotheses, 54(2), 254-262.

Reyes-De-Corcuera, J.I., Cavalieri, R.P., Powers, J.R. (2004). Blanching of Foods. Encyclopedia of Agricultural, Food, and Biological Engineering, Marcel Dekker, Inc.

Uddin Burhan, M., Ainsworth, P., Ibanoglu, S. (2004). Evaluation of mass exchange during osmotic dehydration of carrots using response surface methodology. Journal of Food Engineering, 65, 473-477.

Smout, C., Sila, D.N., Vu, T.S., Van Loey, M.L., Hendrick, E.G. (2005). Effect of preheating and calcium pre-treatment on pectin structure and thermal texture degradation: a case study on carrots. Journal of Food Engineering, 67, 419-425.

Siliha, H., Jahn, W., Gierschner, K. (1996). Effect of a new canning process on cell wall pectic substances, calcium retention and texture of canned carrots. In J. Visser, A. G. J. Voragen (Eds.), 495-508.

Sanjuán, N., Hernando, I., Lluch, A., Mulet, A. (2005). Effects of low temperature blanching on texture, microstructure and rehydration capacity of carrots. J Sci Food Agric, 85, 20712076

Službeni list SFRJ (1983). Pravilnik o metodama uzimanja uzorak i vršenja hemijskih i fizičkih analiza radi kontrole kvaliteta proizvoda od voća i povrća, 29/83

Received: 06. 06. 2016.

Accepted: 10. 04. 2017. 